\title{
Calcification of Intervertebral Dises in the Dachshund: A Radiographic Study of 21 Stud-Dogs
}

\author{
By $\varnothing$. Stigen
}

Department of Small Animal Clinical Sciences, Norwegian College of Veterinary Medicine, Oslo, Norway.

\begin{abstract}
Stigen, Ø.: Calcification of intervertebral discs in the dachshund. A radiographic study of 21 stud-dogs. Acta vet. scand. 1995, 36, 329-334. - The vertebral columns of 21 clinically normal, 4.9 to 13.2 year old dachshunds were $\mathrm{x}$-rayed. This sample represented $55.3 \%$ of all male dachshunds with 20 or more offspring registered with the Norwegian Kennel Club in the period 1985-1989.

Calcified intervertebral discs were identified in $9(42.9 \%)$ of the stud-dogs, and the number of calcified discs in each individual varied from 2 to 5 with a mean of 3.7.

The frequency of stud-dogs with 1 or more calcified discs was compared with the corresponding frequency in a material of 327 one-year-old dachshunds. In this comparison, the relative risk was estimated with $95 \%$ confidence bounds. When the different composition of size and coat varieties in the 2 materials was not considered, the relative risk of calcified discs was found to be 1.77 (0.99-3.2) times higher in stud-dogs than in young dogs. When the different composition of varieties in the 2 materials was considered, the relative risk was found to be 1.9 (1.1-3.4) times higher in stud-dogs than in young dogs. The results of the present study strongly suggest that an increase in the frequency of dachshunds with 1 or more calcified intervertebral discs occurs after 1 year of age.
\end{abstract}

vertebral column; degeneration; dog.

\section{Introduction}

In dogs presented for a medical examination intervertebral disc disease (IDD) is diagnosed with a frequency of $2.0 \%$ (Oliver et al. 1987). Dachshunds are highly susceptible, and the occurrence of IDD in this breed has been estimated to be $19.0 \%$ (Ball et al. 1982).

A dystrophic calcification of the nucleus pulposus is an important predisposing factor of disc protrusions and subsequently of clinically significant IDD in the dachshund (Hansen 1952, Havranek-Balzaretti 1980). A genetic basis for development of calcified discs is suspected in this breed and the heritability is estimated to 0.15 and 0.22 depending on the method used (Stigen \& Christensen 1993).
In a radiographic study (Stigen 1991), calcified discs were estimated to occur in $23.5 \%$ of 12 to 18 months old dachshunds registered with the Norwegian Kennel Club (NKC). In a previous study, Havranek-Balzaretti (1980) found calcified discs in 34 of 45 one to 7 year old dachshunds, and 1 to 5 years later neither the number of affected dogs nor the number of calcified discs in each affected dog was increased. This finding suggested that within an adult population, the proportion of dogs with calcified discs is fairly constant. If this suggestion is valid then the proportion of dogs with calcified discs in Norwegian dachshunds at 12 to 18 months $(23.5 \%)$, should be con- 


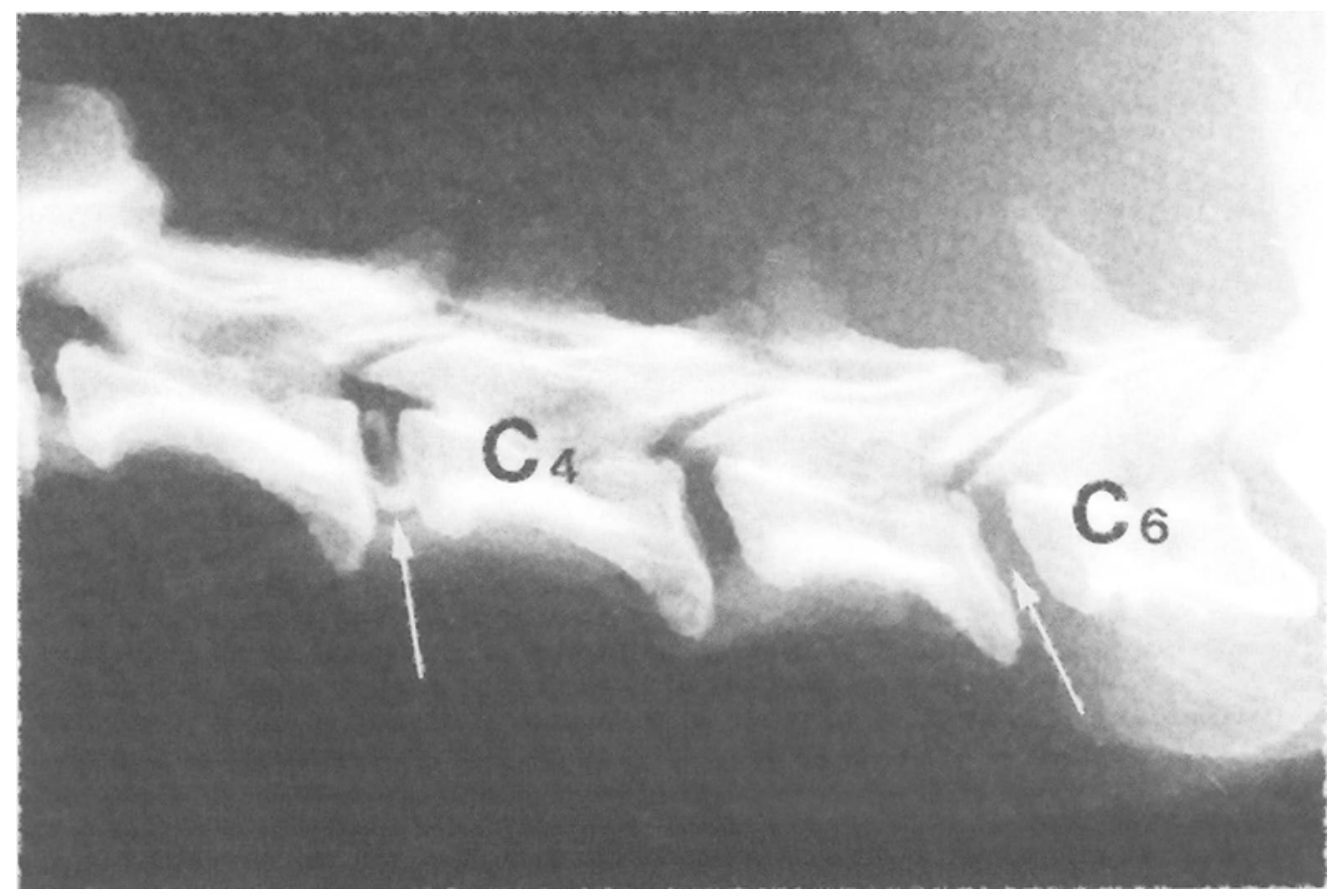

Figure 1. Wirehaired dachshund of standard size, 5 years and 312 days old, with 2 calcified intervertebral discs in the cervical column (arrows). The disc between C5 and C6 has only a small calcification.

stant within the adult population. The present study was performed to test this hypothesis.

\section{Materials and methods}

Written inquiries were made to owners of male dachshunds with 20 or more offspring registered with the NKC during the period 1985-1989. The owners were requested to present their animals for a physical and radiographic examination at the Department of Small Animal Clinical Sciences, Norwegian College of Veterinary Medicine. The dogs were divided into classes based on size and coat variety according to international cynological classification (Fiorone 1973).

A total of 38 stud-dogs met the selection crite- ria of which 21 were available for the examination. The dogs not available for the examination were either dead (10 dogs) or belonged to owners who did not respond to the inquiry ( 7 dogs).

The examined dogs were sires of $19.3 \%$ of all dachshunds registered with the NKC during the selected 5-year-period and were distributed between the following size and coat varieties: 4 standard smoothcoated, 8 standard wirehaired, 5 standard longhaired, 3 dwarf longhaired, and 1 kaninchen longhaired. The age of the dogs ranged from 4.9 years (4 years and 330 days) to 13.2 years (13 years and 62 days) with a mean of 8.0 years $(\mathrm{SD}=2.1$ years). At the time of examination, none had clinical signs of IDD. 
Table 1. The distribution of 348 dachshunds (21 stud-dogs and 327 young dogs) from 2 different studies, on the basis of their size and coat varieties. Dwarf and kaninchen sizes are combined and classified as miniatures. The number of dogs with $(+)$ and without $(-)$ calcified discs from each study is shown. For each variety and relative to the occurrence in young dogs, the relative risk of calcified discs in stud-dogs is presented.

\begin{tabular}{|c|c|c|c|c|c|}
\hline \multirow{2}{*}{$\begin{array}{l}\text { Variety } \\
\text { Coat, size }\end{array}$} & \multicolumn{2}{|c|}{$\begin{array}{c}\text { Stud-dogs } \\
\text { (present study) }\end{array}$} & \multicolumn{2}{|c|}{$\begin{array}{l}\text { Young dogs } \\
\text { (Stigen 1991) }\end{array}$} & \multirow{2}{*}{$\begin{array}{c}\text { Relative risk } \\
{[\mathrm{a}(\mathrm{c}+\mathrm{d}) / \mathrm{c}(\mathrm{a}+\mathrm{b})]}\end{array}$} \\
\hline & $+(a)$ & $-(b)$ & $+(\mathrm{c})$ & $-(d)$ & \\
\hline Smoothcoated, standard & 2 & 2 & 10 & 51 & 3.05 \\
\hline Wirehaired, standard & 2 & 6 & 23 & 62 & 0.92 \\
\hline Longhaired, standard & 3 & 2 & 7 & 70 & 6.60 \\
\hline Wirehaired, miniature & 0 & 0 & 3 & 1 & - \\
\hline Longhaired, miniature & 2 & 2 & 36 & 64 & 1.39 \\
\hline Total & 9 & 12 & 79 & 248 & 1.77 \\
\hline
\end{tabular}

Lateral radiographs of the vertebral columns were taken and read according to earlier described methods of examination (Stigen 1991). For each stud-dog the total number of calcified discs and their location in the vertebral column were recorded.

The frequency of dogs with 1 or more calcified discs was compared to the corresponding frequency in the previous study of young dachshunds (Stigen 1991). In the comparison between these 2 studies, dogs of dwarf and kaninchen sizes were combined and classified as miniatures. Statistical analysis was performed by computing the relative risk of calcified discs versus age. The analysis was done firstly without correction for size and coat varieties (crude relative risk) and then with correction for these varieties (adjusted relative risk) by use of the Mantel-Haenszel estimate in the procedure FREQ in the statistical analyses programme from SAS (SAS Institute Inc. 1989).

\section{Results}

Calcified discs (Fig. 1) were identified in 9 $(42.9 \%)$ of the stud-dogs. The number of dogs with and without calcified discs in different size and coat varieties is presented in Table 1.
A total of 33 calcified discs were found in the 9 affected dogs. The number of calcified discs in each dog ranged from 2 to 5 with a mean of $3.7(\mathrm{SD}=1.2)$. Calcification was identified in each cervical, thoracic and lumbar intervertebral disc except T10-11, T13-L1, L6-7 and L7S1.

For each size and coat variety, the relative risk of calcified discs is presented in Table 1. For the total number of dogs, the estimated crude relative risk was 1.77 with 0.99 and 3.2 as $95 \%$ confidence bounds. The estimated size and coat adjusted relative risk was 1.9 with 1.1 and 3.4 as $95 \%$ confidence bounds.

\section{Discussion}

The percentage of dogs with calcified discs $(42.9 \%)$ and the average number of calcified discs in affected dogs (3.7) in the present study are larger than the corresponding values (24.2\% and 2.3 respectively) in a previous study of young dachshunds (Stigen 1991). However, with regard to location, calcified discs were identified in the cervical, thoracic and lumbar sections of the vertebral column in both studies.

As both the crude and adjusted relative risks were close to 2.0 , the risk of getting calcified 
discs was almost twice as high in stud-dogs compared to 12 to 18 months old dachshunds. This finding also indicates that intervertebral discs which are not calcified in a 1-year-old dachshund can subsequently undergo calcification. However, the number of stud-dogs included in the present study was small, thus the conditions for estimating confidence bounds of the adjusted relative risk were not fulfilled. The confidence bounds are therefore to be understood as approximate.

The average number of calcified discs in affected dogs was found to be larger in studdogs compared to young dogs. This finding and the identified increased risk of calcified discs in stud-dogs are highly suggestive of an age-effect on calcification of intervertebral discs in the dachshund. This suggestion is also in accordance with the age-related increase in number of dogs with calcified discs demonstrated by Hansen (1952). In that study, which included a pathologic examination of 206 chondrodystrophoid dogs, calcified discs were identified in $31.2-62.5 \%$ of 1 -year-old dogs, and the percentage of affected dogs gradually increased to $70.0-90.0 \%$ in 7-year-old dogs.

Although the number of dogs in the present study was limited, all common varieties of dachshunds registered with the NKC were represented. The large percentage of dogs available for examination in the group of stud-dogs that were alive $(75.0 \%)$ is the result of a positive attitude to disease registrationwork among dachshund-breeders.

A genetic basis is suspected for the development of calcified discs in the dachshund (Stigen \& Christensen 1993). It was therefore considered valid to compare the occurrence of such discs in breeding-animals with the occurrence in the next generation of dachshunds. In the present study, all stud-dogs had offspring registered with the $\mathrm{NKC}$ during the period 1985-1989 whereas the young dogs previously examined by Stigen (1991) all were registered with the NKC during the period 1986-1988. Thus, the dachshunds from these 2 studies represented 2 following generations and as such were well suited for the examination of the influence of age on calcification of intervertebral discs.

The present study could be criticised because only male dachshunds were included. However, several studies have shown that calcified discs and IDD in the dachshund are not sexrelated. In studies of IDD, Priester (1976) found $51.8 \%$ of 8117 canine cases in males whereas Ball et al. (1982) found $46.7 \%$ of 536 dachshund cases in this sex. In a radiographic study of young dachshunds, Stigen (1991) found the frequency of calcified discs not to differ among sexes. The results of the present study are therefore expected to be representative of both sexes.

In the present study the percentage of studdogs with calcified discs is probably lower than the expected percentage of dogs with such discs in the total group of stud-dogs defined. As dogs with calcified discs are predisposed to IDD and this disease may result in euthanasia of middle-aged dogs (Funkquist 1962a,b), the inability to examine dead studdogs represents a selection against dogs with such discs. Owners of stud-dogs that have or have had IDD may also be reluctant to present their animals for the present examination and so contribute to selection against dogs with such discs. However, in dogs calcification in discs can also disappear. In a radiographic study of 45 dachshunds, HavranekBalzaretti (1980) found that 14.7 to $23.5 \%$ of the dogs with calcified discs at the time of first examination were without such discs 1 to 5 years later. About $60.0 \%$ of these dogs had shown clinical signs of IDD in the time between the 2 examinations.

The hypothesis tested by the present study 
was based on the work of Havranek-Balzaretti (1980) which showed that none of 45 dachshunds had developed more calcified discs up to 5 years after examination. In that study the dogs had mean ages of 3.1 and 5.4 years at the first and second examination respectively, which differed from the mean ages of 1.2 years in young dogs and 8.0 years in stud-dogs in the present study. Only 11 dogs were 1 year old at the first examination by Havranek-Balzaretti (1980). Thus, the inclusion of few young dogs and an average follow-up time of only 2.3 years in that study may have obscured the age difference that was identified in the present comparison. However, to gain a better understanding of the effect of age on calcification of intervertebral discs in the dachshund, a large sample of young dogs should be examined and followed up with examinations over an extended period.

\section{Acknowledgement}

The author gratefully acknowledges Dr. R. B. Larssen who performed the statistical analysis in this study.

\section{References}

Ball MU, McGuire JA, Swaim SF, Hoerlein BF: Patterns of occurrence of disk disease among registered dachshunds. J. Amer. vet. med. Assoc. 1982, 180, 519-522.

Funkquist B: Thoraco-lumbar disc protrusion with severe cord compression in the dog. II. Clinical observations with special reference to the prognosis in conservative treatment. Acta vet. scand. 1962a, 3, 317-343.

Funkquist B: Thoraco-lumbar disc protrusion with severe cord compression in the dog. III. Treatment by decompressive laminectomy. Acta vet. scand. 1962b, 3, 344-366.

Fiorone F: The encyclopedia of dogs. Hart-Davis, MacGibbon, London 1973, 172-179.

Hansen HJ: A pathologic-anatomical study on disc degeneration in dog. Acta orthop. scand. 1952, suppl. 11, 1-117.
Havranek-Balzaretti B: Beitrag zur Aetiologie der Dackellähme und Vorschlag zur züchterischen Selektion. (The etiology of intervertebral disc disease in the dachshund and proposal of an eradication programme). Veterinär-Chirurgischen Klinik und Institut für Veterinärpatologie, 1980. Dissertation, Universität Zürich, 1980.

Norwegian Kennel Club: Dogs registered with the Norwegian Kennel Club 1985-1989. Datalist 1990.

Oliver JE, Hoerlein BF, Meyhew IG: Veterinary neurology. W. B. Saunders, Philadelphia 1987, 321342.

Priester WA: Canine intervertebral disc disease - occurrence by age, breed and sex among 8,117 cases. Theriogenology 1976, 6, 293-303.

SAS Institute Inc.: SAS/STAT ${ }^{\circledR}$ User's guide. Version 6, 4th ed., vol. 1. Cary, North Carolina; USA 1989, 851-889.

Stigen Ø: Calcification of intervertebral discs in the dachshund. A radiographic study of 327 young dogs. Acta vet. scand. 1991, 32, 197-203.

Stigen Ø, Christensen K: Calcification of intervertebral discs in the dachshund. An estimation of heritability. Acta vet. scand. 1993, 34, 357-361.

\section{Sammendrag \\ Forkalkede intervertebralskiver hos dachshund: \\ En røntgenologisk unders $\emptyset$ kelse av 21 avlshanner.}

Virvelsøylen til 21 klinisk normale dachshunder i alderen 4,9-13,2 år ble unders $\varnothing \mathrm{kt}$ r $\varnothing$ ntgenologisk. Hundene utgjorde $55,3 \%$ av samtlige avlshanner med 20 eller flere avkom registrert i Norsk Kennel Klub i perioden 1985-1989.

Forkalkede intervertebralskiver ble påvist hos 9 $(42,9 \%)$ av hundene. Hos disse var fra 2 til 5 skiver forkalket, med gjennomsnitt på 3,7.

Frekvensen av hunder med en eller flere forkalkede skiver ble sammenlignet med tilsvarende frekvens i et materiale på 327 ett år gamle dachshunder. I denne sammenligningen ble relativ risiko estimert med $95 \%$ konfidensintervall. Når det ikke ble tatt hensyn til de to materialenes ulike sammensetning av størrelses- og hårlagsvarianter, ble den relative risikoen for forkalkede skiver hos avlshannene funnet å være $1,77(0,99-3,2)$ ganger større enn hos de unge hundene. Når det ble tatt hensyn til materialenes 
ulike sammensetning av varianter, ble den relative risikoen for forkalkede skiver hos avlshannene funnet å være 1,9 (1,1-3,4) ganger større enn hos de unge hundene.
Unders $\varnothing$ kelsen indikerer at frekvensen av dachshunder med en eller flere forkalkede intervertebralskiver $\emptyset$ ker etter 1 års alder.

(Received June 27, 1994; accepted May 24, 1995).

Reprints may be obtained from: $\varnothing$. Stigen, Department of Small Animal Clinical Sciences, Norwegian College of Veterinary Medicine, P. O. Box 8146 Dep., N-0033 Oslo 1, Norway. 